\title{
Læringsmål i masteruddannelser - et underviserperspektiv på teori-praksis relationen
}

Annie Aarup Jensen, cand.mag., ph.d., lektor, Institut for Loering og Filosofi, Aalborg Universitet.

Anja Overgaard Thomassen, cand.merc., ph.d., lektor, Institut for Laering og Filosofi, Aal-borg Universitet.

\section{Reviewet artikel}

Artiklen belyser, med udgangspunkt i Ellströms kategorisering af handlings-, vidensog loeringsniveauer (1996), at der eksisterer en generel grundloeggende forskel mellem, hvad underviserne oplever, at masterstuderende har som mål med deres uddannelse, og hvad underviserne selv tolker som det overordnede mål. De studerendes mål er ifølge underviserne overvejende at få teoretisk viden og teoretisk funderede svar på konkrete problemstillinger, mens undervisernes mål er at skabe refleksive praktikere gennem arbejdet med teorier og teori-praksisintegration. Artiklen er baseret på kvalitative interviews med fem erfarne underviserer fra tre forskellige masteruddannelser, hvor kernefelterne er laereprocesser, organisations- og professionsudvikling samt lederudvikling.

\section{Indledning}

Relationen mellem teori og praksis på bachelor- og kandidatuddannelser er et stadigt mere aktuelt emne, der er baseret på mål om at sikre uddannelsernes erhvervsrettethed, samfundsrelevans og fremtidsorientering således, som det eksempelvis kommer til udtryk i de mål, der opstilles for uddannelses- og institutionsakkrediteringer (Danmarks Akkrediteringsinstitution; Institutionsakkreditering).

På de danske masteruddannelser er spørgsmålet om teori-praksisrelationen også relevant, men ud fra andre præmisser, da de studerende har minimum 2 års relevant erhvervserfaring efter gennemført adgangsgivende uddannelse (BEK nr. 1187, § 9, stk. 3) og som følge deraf allerede har en praksiskontekst at relatere en uddannelses faglige indhold til. Masterstuderendes vej ind i teori-praksisrelationen er således den modsatte af bachelor- og kandidatstuderendes.

Der er lavet en del undersøgelser af danske masteruddannelser med fokus på de studerende, eksempelvis studerendes oplevelser af og erfaringer med at være under uddannelse (Stegeager, 2014) og de dårlige rammevilkår voksne studerende tilbydes og byder sig selv (Lorentsen \& Niemann, 2010;), masterstuderendes motivation for masteruddannelse og både personlige og faglige udbytte deraf (Krogh \& Jensen, 2010), kategorisering af masterstuderendes anvendelse af teori i forhold til praksis 
som inspiration for videreudvikling af masterpædagogik (Jensen og Jensen 2004; Aarkrog, 2008) og problemstillinger vedrørende studerendes udfordringer med at bringe viden fra uddannelse ind i egen praksis (Boud \& Garrick, 1999; Keller m.fl., 2011; Stegeager m.fl., 2013; Thomassen og Rasmussen, 2014).

Underviseres oplevelse af og erfaringer med masterstuderende og deres arbejde med teori-praksisrelationen er imidlertid forskningsmæssigt underbelyst i en dansk kontekst (jf. søgning i Google Scholar ud fra: masteruddannelse - underviser - teori praksis - relevans), bortset fra overvejelser over lærerrollen, som eksempelvis i Fibiger (2005), der beskriver lærerrollen i en specifik masteruddannelse som coach og sparringspartner, samt hos Ry-Nielsen (2008), der med afsæt i Master in Public Administration (MPA) beskæftiger sig med spørgsmålet om nyttiggørelse af deltagernes erfaringer i undervisningssituationen og i opgaver.

Da underviseren er en vigtig aktør også i voksenuddannelse (Illeris, 2003), har vi valgt at undersøge, hvilke opfattelser, erfaringer og værdier, masterundervisere giver udtryk for. Hvilke mål oplever underviserne, at de masterstuderende møder ind med: kommer de for at fordybe sig i teorier eller for "at få værktøjskassen fyldt op" med konkrete modeller, eller har de andre mål? Hvorledes arbejder underviserne med at skabe forbindelse mellem uddannelse og praksis? Og hvilken udvikling hos de masterstuderende vil undervisere gerne understøtte?

De udvalgte undervisere i undersøgelsen har over årene opnået stor erfaring og viden inden for undervisning på masteruddannelser, og de er meget bevidste og reflekterede omkring deres undervisning. Undersøgelsen, der ligger til grund for denne artikel, vidner om dette, både hvad angår overvejelser over undervisningsplanlægning og over teori- og begrebsdannelse om undervisning jf. Dales kompetenceniveauer for pædagogisk professionalitet (Dale, 1998). Underviseres forståelse af deres egen praksis med alt, hvad den indebærer, indgår i det, Dale benævner 'perceptuelle vaner', det vil sige, de fortolkningsmønstre, som anlægges på læringssituationer som helhed, og som dermed også er med til at definere det handlingsrum og de handlemuligheder, som underviseren oplever at have (Ibid., s. 89). Vi er derfor interesserede i, hvad der fremkommer gennem undersøgelsen af, hvordan underviseropgaven med særligt henblik på teori-praksisrelationen på en masteruddannelse fortolkes af erfarne masterundervisere: hvordan beskriver underviserne masterstuderendes arbejde med teori og praksis, og hvorledes stemmer undervisernes opfattelse af studerendes mål med uddannelsen overens med undervisernes mål?

\section{Metode}

Artiklen baserer sig på individuelle, semi-strukturerede og kvalitative interviews med fem erfarne master-undervisere (to kvinder og tre mænd), der alle er tilknyttet en af de tre masteruddannelser, der danner grundlag for undersøgelsen. Kernefelterne på disse uddannelser kan bredt siges at være læreprocesser, organisations- og profes- 
sionsudvikling samt lederudvikling. I vores tilgang til interviewene anlagde vi en eksplorativ tilgang med en interviewguide baseret på seks temaer med åbne spørgsmål. De seks temaer var: underviserens felt og erfaringsbaggrund; målgruppen; målgruppeorienteret undervisningstilrettelæggelse; akademiske kompetencer; praksisrelation; underviserens udfordringer, værdier og rationaler. Underviserne blev udvalgt ud fra følgende kriterier: mangeårig erfaring med undervisning og vejledning på masteruddannelse; forskellige masteruddannelser repræsenteret; fordeling på køn. Vi har således arbejdet ud fra det eksemplariske princip, hvor vi gennem analysen af det indsamlede empiriske materiale vil opnå forståelser, der kan bidrage til den bredere debat omkring uddannelsesmål for masteruddannelser.

Med afsæt i interviewtransskriptionerne gennemførte vi en analyse inspireret af Giorgis (1992; 1994) fænomenologiske analysemetode. Efter en række gennemlæsninger af materialet blev der foretaget en meningskondensering af afsnittene, som ledte frem til en række emner, hvoraf vi i denne artikel særligt fokuserer på undervisernes opfattelser og kategoriseringer af de studerendes syn på og brug af teori i relation til praksis og undervisernes overvejelser over betydningen af studerendes syn på teori-praksisrelationen i forhold til at skabe forbindelse mellem disse. Analyserammen for dette har været Ellströms model for kategorisering af handlings-, videns- og læringsniveauer (Ellström, 1996), og især niveau to (Regelbaseret handling), tre (Vidensbaseret handling) og fire (Refleksiv handling) var relevante for analysen. Modellen (Fig. 1) kan kort forklares således: Metodestyrede læreprocesser, hvor opgaven og metoden er givet på forhånd, men resultatet ukendt, fører ifølge Ellström til know-how og regelbaseret handlingskompetence. Problemstyrede læreprocesser, hvor opgaven er givet, men resultatet ukendt, og den lærende selv vælger metode, fører til vidensbaseret handlingskompetence, hvor analytisk tænkning og teoretisk viden indgår. Det refleksive handlingsniveau nås gennem kreative læreprocesser, hvor hverken opgave, metode eller resultat er givet på forhånd, og hvor der indgår meta-kognitive processer, distancering, kritisk analyse og refleksion.

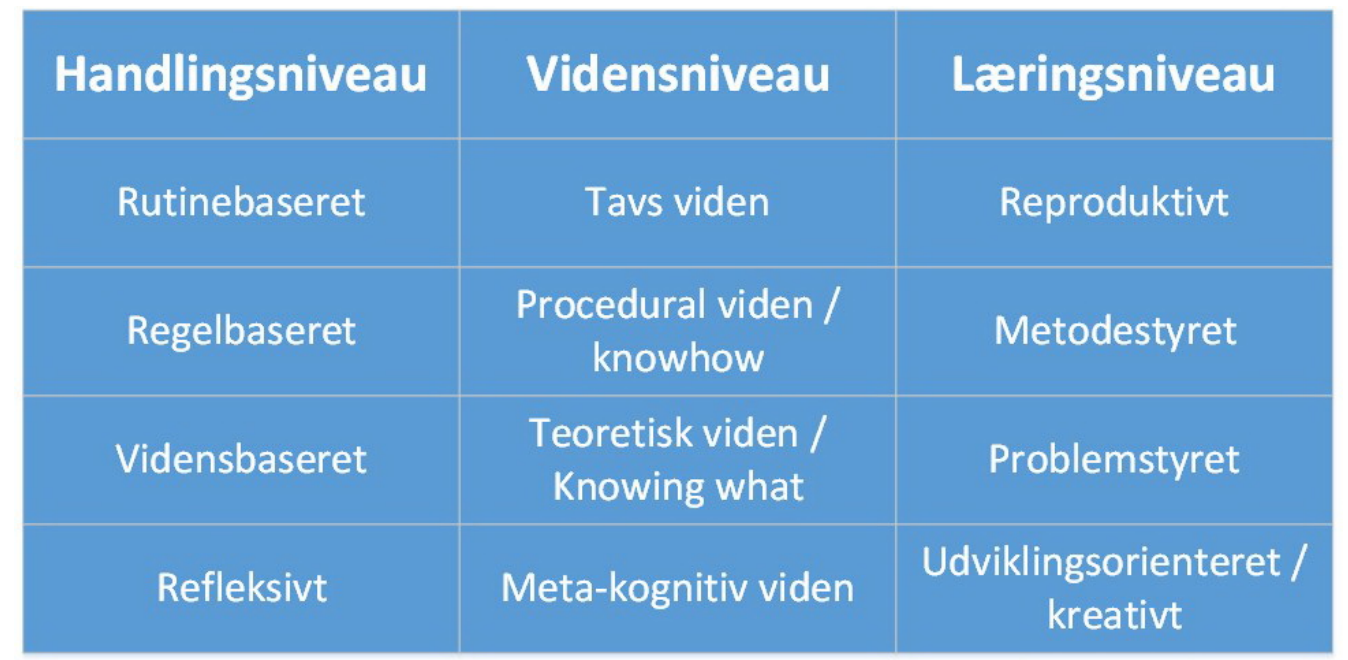

Fig. 1: Oversat fra Ellström 1996, s. 160. 
Da der er tale om fem undervisere i forskellige fag på tre forskellige uddannelser, har vi ikke ladet en bestemt definition bestemme begrebet 'teori' men har ladet det stå åbent for de enkelte undervisere at vurdere, hvornår og hvordan det var relevant for dem at tale om teori i forhold til deres uddannelseskontekst. Underviserne vil i det følgende blive refereret til som A, B, C, D og E.

\section{Undersøgelsens kontekst: Tre typer af masteruddannelser}

Vi tager som nævnt afsæt i en undersøgelse af fem undervisere, der er tilknyttet tre forskellige masteruddannelser. Det skal overordnet bemærkes, at da alle uddannelserne ligger ved et PBL-universitet (Problem Baseret Læring), indgår der, i forskelligt omfang, større problemorienterede projektarbejder på alle uddannelserne. Disse udarbejdes oftest i relation til en eller flere praksiskontekster. Imidlertid viste det sig, på baggrund af henholdsvis uddannelsernes studieordninger og undervisernes udsagn og kategoriseringer af "deres" uddannelser, at der tegnede sig et billede af disse uddannelsers forskellighed i forhold til, hvorledes der ud over projektarbejdet arbejdes med at sammenkoble praksis og uddannelse. Uddannelserne kan indplaceres på et kontinuum, hvor det ene yderpunkt udgøres af den "fleksible" master der består af en række moduler, hvoraf fire er obligatoriske. Modulernes rækkefølge er ikke forudbestemt, hvorfor der ej heller er en naturlig progression indlejret i forløbet (Masteruddannelse X). Det andet yderpunkt indtages af den "ufleksible" master, hvor der er tydelig planlagt progression understøttet af et stringent undervisningsdesign (Masteruddannelse Z). Mellem de to yderpunkter finder man en masteruddannelse, der dels har progression i form af obligatoriske moduler, der fører frem til specialiseringsvalg, dels har stor valgfrihed i opgaver og projektemner (Masteruddannelse Y).

Uddannelsernes forskellighed viser sig også i, hvorledes man i undervisningen arbejder med teori-praksisrelationen og inddrager de studerendes egen praksis i undervisningen. I Masteruddannelse $Y$ arbejder man på uddannelsens seminarer med oplæg med en overvægt af teoretisk indhold samt med forskellige former for praksisrelaterede øvelser:

"Vi gennemgår ikke kun en proces, men samler altid op: hvad er det forskningsmaessige belaeg, hvilke teorier er der på området, hvilken teoretisk ramme, kan det forstås fra andre perspektiver. ... [det] gør det nemmere at tale om de her ting, at vi taler om konkrete erfaringer, de studerende lige har haft" (A).

Ovenstående citatet viser, at undervisningen er orienteret mod, at de studerende i undervisningstiden afprøver forskellige metoder og teknikker på egen krop. Underviserne søger gennem øvelserne at skabe forbindelse mellem uddannelse og praksis, idet metoderne ikke blot afprøves, men hvor det teoretiske fundament også diskuteres og relateres til de studerendes praksis. 
En anden måde at arbejde med teori-praksisrelationen ses på Masteruddannelse X. Her er der fire obligatoriske moduler, og der er ikke en fastlagt progression i uddannelsen. De studerende bestemmer selv, hvilke moduler de tager og på hvilket tidspunkt i uddannelsesforløbet, hvilket skal understøtte teori-praksisrelationen, fordi moduler vælges ud fra faglig interesse eller ud fra en aktuel problemstilling i praksiskonteksten. I særligt et modul med fokus på det personlige lederskab, hvor der fokuseres på at udvikle lederens evne til at udvikle egen ledelse, skal de studerende så at sige studere sig selv og deres egen ledelse. Et element i undervisningen er, at hver enkelt studerende får besøg af 2-3 medstuderende i egen organisation, der fx observerer møder eller interviewer værtens kolleger ud fra en selvvalgt problemstilling. De studerendes engagement i hinandens ledelsesmæssige udfordringer understøtter ifølge underviseren muligheden for at skabe forbindelse mellem praksis og uddannelse.

"[...] at gå ind i hinandens problemstillinger, [...] at gå ind og diskutere hinandens, og hvis man kan skabe et engagement af det, så synes jeg, det kører, fordi så bliver det nemmere at trakke teorier ind og forstå, hvad pokker man kan bruge teorier til" (E).

I Masteruddannelse Z tager man skridtet videre, idet de studerende skal iværksætte et eksperiment i egen praksis, og underviseren følger så at sige med ud i praksis og fungerer som "bagmandskonsulent". Underviseren forklarer det således:

"Og på Master Z [...] så fra 2. semester og i hvert fald 3. semester og ofte også 4. semester, der skal de studerende ud og lave praksis. Et eller andet omstillings-, noget de eksperimenterer med i egen organisation. Og så er jeg sådan bagmandskonsulent. Og på Master Z siger vi jo, at vejleder kan vaere medforsker. Så jeg kan komme meget langt ind $i$ at voere en slags bagmandskonsulent" (D).

I alle tre scenarier handler det om at inddrage konkrete praksiselementer som hjælp til forståelse af eller understøttelse af arbejdet med uddannelsens teorier, og læreprocessen forudsætter i alle tre sammenhænge aktiv deltagelse. Som det ses enten gennem simulering/øvelser (Master $Y$ ), gennem at skabe den analytiske distance til en praksis, der kan opnås ved, at det ikke er ens egen praksis, der undersøges og diskuteres (Master $\mathrm{X}$ ) eller ved, at der er tæt tilknytning til vejleder, når man laver eksperiment i egen praksis og dermed har en kompetent sparringspartner (Master Z). 


\begin{tabular}{|c|c|c|}
\hline Masteruddannelse X & Masteruddannelse $Y$ & Masteruddannelse Z \\
\hline $\begin{array}{ll}\text { - } & \text { Fleksibel master- } \\
\text { - } & \text { } \text { Fire obligatoriske } \\
& \text { moduler } \\
\text { - } & \text { Ingen bestemt } \\
\text { - } & \text { rækkefølge } \\
\text { Ingen fastlagt } \\
\text { - } \\
\text { Opogression } \\
\text { Opgave følger } \\
\text { modulets tema }\end{array}$ & $\begin{array}{ll}\text { - } & \text { Obligatoriske mo- } \\
\text { duler } \\
\text { - } \\
\text { Uddannelsens fast- } \\
\text { lagte forløb kan af- } \\
\text { viges } \\
\text { - } \quad \text { Progression } \\
\text { - } \quad \text { Specialiseringsvalg } \\
\text { - } \quad \text { Valgfrihed i opga- } \\
\text { ver/projekter inden } \\
\text { for semestrets te- } \\
\text { maramme }\end{array}$ & $\begin{array}{ll}\text { - } & \text { Uddannelsen følger } \\
& \text { fast struktur } \\
\text { - } & \text { Progression } \\
\text { - } & \text { Stringent undervis- } \\
& \text { ningsdesign } \\
\text { - } & \text { Underviser } \\
& \text { /studerende relation }\end{array}$ \\
\hline \multicolumn{3}{|c|}{$\begin{array}{l}\text { Uddannelsernes kontekstuelle læringsrum } \\
\text { - valg af teori/praksis tilgang i undervisningen }\end{array}$} \\
\hline $\begin{array}{l}\text { Besøg af medstuderende } \\
\text { i egen organisation }\end{array}$ & $\begin{array}{l}\text { Problembaserede opga- } \\
\text { ver/øvelser i læringsrum- } \\
\text { met }\end{array}$ & $\begin{array}{l}\text { Eksperiment i egen organisa- } \\
\text { tion }\end{array}$ \\
\hline
\end{tabular}

Fig. 2: Sammenfatning af masteruddannelsernes kendetegn.

\section{Undervisernes oplevelse af masterstuderende}

Underviserne omtaler de studerende som "engagerede", "motiverede", og "uddannelsesglade" med "stor spørge- og diskussionslyst". De vurderer, at de studerendes store styrke er, at de kan relatere til deres konkrete praksiserfaring og -kontekst:

"Deres styrker er en ofte ret grundig og reflekteret praksis og så et engagement. Altså, de kommer også, fordi de gerne vil det og vil have noget ud af det" (B).

De studerendes tætte relation til egen praksis indebærer i nogle underviseres fortolkning også en emotionel relation, som underviserne oplever kan medføre læringsmæssige udfordringer for de studerende, når egen praksis skal reflekteres teoretisk.

"Styrke [...] de har noget konkret praksis at relatere til, når vi taler om teorier. [...] men det [...] kan godt vaere sådan lidt et tveaegget svard, fordi det godt nogle gange kan vare vanskeligt for dem at lave den modsatte bevagelse, altså trakke deres konkrete oplevelser op på et mere refleksivt plan med teoretiske begreber og distancere lidt fra, måske, hvad de involverede lige sådan følelsesmaessigt og kropsligt og sådan. [...] Det er på samme tid både en styrke og en svaghed, den der kropslige erfaring og involverethed og emotionelle kobling faktisk til teoretiske begreber [...] og selvfølgelig også den samme koblethed til deres praktiske erfaring. Men det er i hvert fald en drivkraft på rigtig mange planer, denne her toette kobling $[\ldots]^{\prime \prime}(\mathrm{A})$. 
Dette kan også have betydning i forhold til undervisernes frihed ved valg af undervisningsindhold, idet det fx kan betyde, at studerende helst skal kunne genkende en umiddelbar praksisrelevans, som det også er beskrevet af Aarkrog (2008):

"Altså, du kan jo ikke stå og sige noget, de ikke på en eller anden måde kan relatere eller i hvert fald, hvis de tænker sig godt om, kan relatere, ellers så synes de altså, det giver jo ikke nogen mening for dem. Så det skal jo hele tiden vaere spot on $i$ forhold til noget, der kan berige deres praksis. Og det er jo det, der gør det nemt at undervise den gruppe" (B).

På den ene side kan praksisrelationen således gøre undervisningsopgaven lettere, på den anden side kan den virke begrænsende for underviserens stofvalg og udgøre en hindring (i forhold til at skabe analytisk distance), som den studerende må lære at håndtere undervejs i uddannelsen. Den sammenkobling mellem det emotionelle og de fysiske erfaringer i relation til studerendes egen praksis, som underviseren ovenfor mener at se, kan med reference til Ellströms kompetencebegreb (Ellström, 1996, s. 149) forstås som et udtryk for en faglig identitet og kompetence, som er udviklet i tæt sammenhæng med den faglige, sociale og kulturelle kontekst, som praksis udgør. Til dette hører også et tanke- og normsæt for den pågældende praksis, som den studerende så at sige skal kunne sætte sig ud over for at kunne skabe den analytiske distance. En hjælp til denne proces kan være de teorier og modeller, som uddannelsen tilbyder.

\section{Studerendes anvendelse af teori i masteruddannelserne}

Ifølge underviserne kan man i de studerendes arbejde se nogle mønstre i forhold til, hvorledes studerende opfatter og anvender uddannelsernes teorier. ${ }^{1}$ Dette har indflydelse på de muligheder og udfordringer, der eksisterer i forhold til at skabe forbindelse mellem uddannelse og praksis og dermed også for læringspotentialet. En underviser giver således udtryk for, at nogle studerende anvender teori til at definere egen praksis og ikke meget mere:

"Se, der er noget af min praksis, der passer på den her teori" (E).

Ved en umiddelbar og måske ukritisk oplevelse af at genkende egen praksis i en teoretisk ramme risikerer den studerende at stille sig tilfreds med tilpasningsorienterede læreprocesser, som er betydningsfulde for at skabe stabilitet i en praksiskontekst, men som samtidig mindsker muligheden for innovation og nytænkning - det som Ellström benævner 'udviklingsorienterede læreprocesser' (Ellström, 1996, s. 163).

\footnotetext{
${ }^{1}$ Teori forstås i denne artikel som de teorier, modeller og begreber, der anvendes inden for undervisernes fagfelter.
} 
I forlængelse af dette fortæller samme underviser, at der kan opleves en forestilling om, at hvis teorien opleves at stemme overens med praksis, så leverer den også et udtømmende svar på problemstillingen:

"Nårh, ja, hvis jeg nu har argumenteret for, at det passer med teorien, så må det jo vare nok'. Og det betyder jo bare i bund og grund, at de bortser fra deres egen praksis og den forståelse, en sådan praksis giver" (E).

Som underviseren påpeger, gives teorien her overvægt på bekostning af de erkendelsesmuligheder, en dybere undersøgelse af egen praksis kunne give. Den faglige kompetence, som den studerende har udviklet gennem sin praksisrelation, skal gerne bringes i spil af den studerende, og manglende teori-praksis-refleksion kan også her føre til tilpasningsorienterede læreprocesser. En anden side af denne problemstilling er de situationer, hvor det forventede svar fra teorien udebliver:

"Nu underviser jeg jo inden for noget, der er enormt anvendelsesorienteret, altså [...] det ved de alle sammen alt om på forhånd. De andre fag, som vi underviser $i$, det ved de også alt om på forhånd. Og så må der vare nogle fine teorier, der giver dem svarene. Når de så når frem til, at de der fine teorier ikke giver dem svarene, så "Hvad er det her nu for noget? Kunne vi ikke bare få et svar? Nu er vi kommet her for et svar?" Og det er jo, altså hvis man accepterer det, så tror jeg, at man har problemer med at opøve deres analytiske evner" (E).

Her ses igen. hvorledes underviseren relaterer sin forståelse af de studerendes opfattelse af, hvad teori er, og hvad teori skal kunne i forhold til praksis, til hvilke problemstillinger, denne tilpasningsorienterede læringstilgang medfører rent uddannelsesmæssigt med hensyn til at udvikle de grundlæggende akademiske færdigheder, som eksempelvis at kunne analysere.

Undervisernes oplevelse er, at der hos de studerende synes at ligge en opfattelse af teori som en form for autoritet, der ikke kan diskuteres eller sættes spørgsmålstegn ved, hvilket i sig selv kan være en hindring for en udviklingsorienteret læringstilgang. I forhold til dette giver flere af underviserne udtryk for, at det for dem er vigtigt, at de studerende aflægger sig en autoritativ holdning til teorierne og får en mere nuanceret forståelse af, hvad teori kan bidrage med. En underviser giver udtryk for sin egen holdning:

"[...] altså, jeg har det jo sådan med teori, at det er vigtigt, men det er jo også noget, som man kan tillade sig at vaelge og tilpasse efter situationen [...]" (B).

"[...] Det, at teorier er altså sådan noget, man godt kan tillade sig at bruge lidt pragmatisk og måske klippe lidt i stykker og bruge lidt af det og måske ikke noget andet" (B). 
Underviserne oplever altså en divergens mellem, at de anskuer teorier som afsæt til at undersøge, diskutere og opnå nye erkendelser, mens de opfatter, at de studerende, generelt set kan have en tendens til at anskue teorier som værende sande billeder af verden eller deciderede handlingsanvisninger.

\section{Resultater sat i forhold til handlings-, videns- og læringsniveauer}

Følger vi undervisernes vurdering af de studerendes forhold til at arbejde med teori, kan vi med Ellströms kategorisering (Ellström, 1996) se, at underviserne oplever, at en del studerende tenderer mod en 'tilpasningsorienteret læring', hvor de søger at løse eller forstå de praksisorienterede problemer ud fra de "regler" eller principper, som de tolker, at en given teori opstiller, uden at stille spørgsmålstegn ved dette som løsningsmodel. Dette tilhører lavere-ordens-læring, mens højere-ordens-læring betyder, at hverken problemet, målet eller forudsætningerne tages for givet men i stedet undersøges. Dette betegner Ellström som 'udviklingsorienteret læring'.

Ifølge underviserne er der nogle studerende, der tydeligt ønsker værktøjer og metoder, tips og tricks til problemløsning og således vil stille sig tilfredse med at vide, hvordan noget skal løses. Det svarer til det, Ellström benævner 'procedural viden' og er et udtryk for metodestyret læring (se fig. 1). Andre studerende arbejder med teoretisk viden, men anvender den, som var der tale om procedural viden, altså som regler, der kan følges, hvilket - hvis Ellströms model følges - betyder, at de faktisk på trods af problemstyret arbejde (PBL) risikerer ikke at hæve sig op på det videns- og handlingsniveau, der i Ellströms model hører til dette niveau, men stadig befinder sig på det regelbaserede og dermed tilpasningsorienterede læringsniveau.

\begin{tabular}{|c|c|c|c|}
\hline & & $\begin{array}{l}\text { pjer", } \\
\text { der, } \\
\text { ricks" }\end{array}$ & \\
\hline Handlingsniveau & Vidensniveau & \multicolumn{2}{|c|}{ Læringsniveau } \\
\hline Rutinebaseret & Tavs viden & \multicolumn{2}{|c|}{ Reproduktivt } \\
\hline Regelbaseret & $\begin{array}{c}\text { Procedural viden/ } \\
\text { knowhow }\end{array}$ & \multicolumn{2}{|c|}{ Metodestyret } \\
\hline Vidensbaseret & $\begin{array}{l}\text { Teoretisk viden/ } \\
\text { knowing what }\end{array}$ & \multicolumn{2}{|c|}{ Problemstyret } \\
\hline \multirow[t]{2}{*}{ Refleksivt } & Meta-kognitiv viden & \multicolumn{2}{|c|}{$\begin{array}{l}\text { Udviklingsorienteret/ } \\
\text { kreativ }\end{array}$} \\
\hline & $\begin{array}{l}\text { Underviserens } \\
\text { mål }\end{array}$ & & $\begin{array}{l}\text { Autoritativ } \\
\text { teoriforståelse/ } \\
\text { anvendelse }\end{array}$ \\
\hline
\end{tabular}

Fig. 3: Oversat fra Ellström 1996, s. 160 - suppleret med forfatternes bokse. 
Det træder frem, at underviserne på tværs af de tre masteruddannelser oplever, at teori-praksisrelationen kan "spænde ben" for de højere læringsniveauer. Samtidig fremgår det af undervisernes udsagn, at det systematiske arbejde, der som nævnt på forskellig vis er integreret i uddannelserne, skaber rammer for at udfordre de studerende på netop de nævnte vidensniveauer ved hjælp af krævende, involverende læreprocesser. Underviserne giver således udtryk for, at der gennem disse udviklingsorienterede læreprocesser for mange studerendes vedkommende nås det refleksive handlingsniveau.

\section{Hvad vil underviserne gerne opnå?}

Gennemgående for underviserne er netop deres ønske om, at de studerende bliver i stand til at tænke på nye måder, hvilket eksempelvis indebærer, at de kan forholde sig til og anvende teori reflekteret i analysen af det undersøgte problem. De ønsker, at de studerende bevæger sig over i refleksiv handling, jf. Ellströms læringsniveau for kreativitet og udviklingsorientering. En af underviser udtrykker sig på følgende måde:

"[...] Hvis jeg skal voere lidt fraek, så vil jeg sige jeg er lidt ligeglad med, hvilke teorier de kan. Det interesserer mig overhovedet ikke. Det der interesserer mig, det er, hvis de bliver proesenteret for en ny teori, som de ikke har set før, hvad vil de stille op med den? Hvordan vil de håndtere den? Hvordan vil de bruge den? Jeg bliver mere og mere ligeglad med, om de kan den model, eller den teoretiker eller den teori, det er ikke det vaesentligste. Det vaesentligste er, hvordan de er i stand til at (bruge den) $[. . .]^{\prime \prime}(\mathrm{D})$.

"[...] så mener jeg i hvert fald selv det handler om, hvordan de er i stand til at vende rundt og endevende en problemstilling og finde ud af, hvad er det for nogle redskaber, jeg kan tage i anvendelse? Er der nogen teorier, der kan inspirere mig?" (D).

Det interessante er her, at det, som det fremgår af ovenstående citater, i mindre grad er det specifikke faglige indhold, som underviserne ser som idealudbyttet af en masteruddannelse. Det synes i højere grad at være de grundlæggende akademiske færdigheder, som at kunne sætte sig ind i nyt stof (herunder teori), at kunne analysere, fortolke, kritisk vurdere anvendelighed i forhold til konkret kontekst og implementere - samt reflektere over situation og proces. Teori kan ifølge underviserne anvendes til at inspirere, og man kan pragmatisk vælge at anvende dele af teorier, men ifølge Ellströms model forudsætter dette, at den studerende har nået det refleksive handlingsniveau gennem udviklingsorienterede læreprocesser. Hvis studerende ikke er villige til eller i stand til at sætte deres eksisterende viden og erfaring i eller på spil, afskærer de sig fra at bevæge sig op på et højere refleksivt niveau. Underviserne anerkender vanskeligheden i at anlægge den analytiske distance til egen 
praksis og egen viden, der er nødvendig for at kunne anskue viden, praksis og teori fra nye vinkler, men det er netop, hvad underviserne gennem deres undervisning gerne vil facilitere.

Når undervisererne giver udtryk for, at de gerne vil uddanne de studerende til at blive refleksive praktikere, så ligger der i deres forståelse af dette begreb, at de ønsker, at de studerende har en teoretisk referenceramme at trække på, og kan sætte sig ind i nye teorier, at de med de analytiske færdigheder kan skabe den nødvendige distance til egen praksis, og at de, selv om de har den teoretiske ballast, også formår at løsrive sig fra den. Det vil sige, at de ikke anvender teorier som løsninger eller handlingsanvisende, at de vover at arbejde kreativt og konstruktivt med teorierne og i det hele taget har et mindre autoritativt forhold til teorierne.

\section{Teori og praksis som læringsmål og -middel i uddannelserne}

Når vi sammenholder undervisernes beskrivelser af deres opfattelse af de studerendes arbejde med teori og praksisrelaterede metoder og af deres oplevelse af de studerendes mål for deres uddannelse med undervisernes egne mål for uddannelserne, ser vi tegn på en væsensforskel mellem, hvad der synes at blive opfattet som mål og middel i uddannelserne. De studerendes overordnede mål er, ifølge underviserne, at lære en række teorier, og de akademiske grundfærdigheder synes at spille en mindre rolle som middel til at lære disse. For undervisernes vedkommende synes det modsatte, lidt firkantet sagt, at være tilfældet: målet er for dem, at de studerende tilegner sig de akademiske, videnskabelige kompetencer, og arbejdet med teori og praksis udgør midlet til at opnå disse kompetencer. I dét lys kan man forstå uddannelsernes forskellige måder at arbejde på med de studerendes teoripraksisrelation som metoder ad hvilke, de studerende udfordres optimalt i forhold til at tilegne sig og udvikle disse kompetencer. Det interessante er således undervisernes grundlæggende forståelse af, at det er de generiske kompetencer relateret til "at lære at lære" og "at lære at tænke sig om", som underviser E udtrykker det, der i deres optik skal bidrage til, at masterstuderende bliver gode praktikere - også på længere sigt, når den viden, de har arbejdet med på uddannelsen, ikke længere er den nyeste, eller når de står over for nye, uforudsete problemstillinger.

Ovenstående pointer er relevante, ikke blot i forhold til nærværende undersøgelse, men også i et bredere underviserperspektiv, idet aspektet om "at lære at lære" retter sig mod en generel diskussion vedrørende universitetspædagogik. Undersøgelsens udsigelseskraft kan, på baggrund af det relativt begrænsede datagrundlag fra beslægtede masteruddannelser på et PBL-universitet, siges at være forholdsvis lille. Artiklen peger trods dette på vigtige områder, man som underviser med fordel kan inddrage i sine didaktiske overvejelser, særligt at teori-praksis-relationen kan stå i vejen for, at den masterstuderende opnår læring på højere læringsniveauer, og at målet med uddannelse muligvis divergerer mellem underviser og masterstuderen- 
de. Dette kan pege på nødvendigheden af en måske endnu højere grad af italesættelse af på den ene side masterstuderendes ønsker for og mål med uddannelsen og deres individuelle læringssyn og, på den anden side, undervisernes læringsmål for de masterstuderende og de tilhørende pædagogiske overvejelser om mål og middel. Artiklens fund er, også i en bredere universitetspædagogisk kontekst, relevante at forholde sig til, idet en opmærksomhed herpå kan understøtte et positivt læringsudbytte hos de studerende.

Annie Aarup Jensen er lektor, og har mange års erfaring med tilretteloeggelse af og undervisning på masteruddannelser og kandidatuddannelser.

Hendes forskningsinteresser fokuserer primart på voksnes loereprocesser $i$ forskellige kontekster samt på problemorientering i uddannelser.

Anja Overgaard er lektor i Organisatorisk Loering, hvor hun sœerligt har beskaftiget sig med forskellige typer af samarbejdsformer mellem universiteter og organisationer - eksempelvis praksisnaer kompetenceudvikling. Gennem en årraekke har Anja undervist på flere forskellige masteruddannelser, hvilket har lagt grundstenen til hendes interesse for, hvorledes der kan arbejdes med at etablere frugtbare loereprocesser i feltet mellem masteruddannelse og organisatorisk praksis.

\section{Litteratur}

Bekendtgørelse om masteruddannelser ved universiteterne (masterbekendtgørelsen). Bekendtgørelse nr. 1187 af 7. December 2009. Retsinformation

Boud, D \& J. Garrick (1999). Understanding learning at work. London: RoutledgeDale, E.L. (1998) Poedagogik og professionalitet. Århus: Klim

Danmarks Akkrediteringsinstitution, http://akkr.dk/2015/passer-de-studerendeskompetencer-til-fremtidens-behov/ Download 20151209

Ellström, P.-E. (1996). Rutin og refleksion. Förutsättningar och hinder för lärande i dagligt arbete. I Ellström, Gustavsson \& Larsson (red.): Livslångt lärande. Lund: Studentlitteratur.

Fibiger, B. (2005). Videndeling i læringsforløb - erfaringer fra undervisning på Masteruddannelsen i Ikt og Læring. Tidsskrift for universiteternes efter- og videreuddannelse (ISSN 1603-5518), 2(5).

Giorgi, A. (1994). A Phenomenological perspective on certain qualitative research methods. Journal of Phenomenological Psychology, 25(2), 190-220.

Giorgi, A. (1992). Description versus Interpretation: Competing alternative strategies for qualitative research. Journal of Phenomenological Psychology, 23(2),119-135. Illeris, K. (2003). Voksenuddannelse og voksenloering. Learning Lab Denmark. Roskilde Universitetsforlag. 
Institutionsakkreditering, http://akkr.dk/vejledninger/institutionsakkreditering/ Download 20151209

Jensen, C. N. (red.) (2005). Voksnes loeringsrum, Værløse: Billesø \& Baltzer.

Jensen, A. A. \& Jensen, H. B. (2004). Back to the future. Theory and practice in adult practitioners' problem oriented project work. I A. Kolmos, F. K. Fink, L. Krogh (red.): The Aalborg PBL model. Progress, Diversity and Challenges. Aalborg: Aalborg University Press.

Keller. H. D., Willert. S. \& Stegeager, N. (2011). Efteruddannelse som ledelsesudfordring - på sporet af en akademisk praksisuddannelse. I: Helth (red.): Ledelse og loering i praksis. Frederiksberg: Samfundslitteratur.

Krogh, L. \& Jensen, A. A. (2010). Lifelong Learning: personal development or professional competence development? I C. Rust (red.) Improving Student Learning. For the Twenty-First Century Learner. Oxford Brookes University.

Lorentsen, A, \& Niemann, K. (2010). 150 km/t på en grusvej: Om voksnes rammer for efter/videreuddannelse. Aalborg: Aalborg Universitetsforlag.

Ry-Nielsen, J. C. (2008). Deltagerorientering i undervisningen af MPA studerende refleksioner og praksis. Dansk Universitetspaedagogisk Tidsskrift, nr. 5, 39-44.

Stegeager, N. (2014). Viden i bevaegelse: En undersøgelse af masterstuderende $i$ spoendingsfeltet mellem uddannelse og arbejdsplads. Ph.d.-afhandling. Institut for Læring og Filosofi, Aalborg Universitet.

Stegeager, N., Thomassen, A. O. \& Laursen, E. (2013). Problem based learning in continuing education - challenges and opportunities. Journal of Problem Based Learning in Higher Education, 1(1), 151-175.

Thomassen, A. O. \& Rasmussen, J. G. (2014). Udvikling af kompetence til ledelse i hverdagen. I Larsen \& Rasmussen (red.): Relationelle perspektiver på ledelse. København: Hans Reitzels Forlag.

Wahlgren, B. (2010). Voksnes Ioreprocesser. Kompetenceudvikling i uddannelse og arbejde. København: Akademisk Forlag.

Aarkrog, V. (2008). Masterstuderendes kobling af teori og praksis. Inspiration til videreudvikling af masterpædagogikken? Dansk Universitetspœedagogisk Tidsskrift, 3(5). 